Conchesion.

This is not the occasion to enter deeply into the ethicnl problems as to the attitude of the public in regard to fractures. It is nevertheless a question which largely affects us. Patients who call upon me are often armed with $x$-ray prints, which they authoritatively expound. Anything but a faultless end-to-end apposition imparts a warlike spirit. 'Twelve months ago a cadaverous nemiotic called upon me. Ho unfolded four $x$-ray prints and typewritten notes, with all the gesture appertaining to the criminal bar. The tibia was slightly overlapping. The function of the limb had been perfect for a year, but when he saw the crooked bone he was reminded, he said, of pains which he sometimes felt. He had climbed the Schilthorn since his injury, but would he not be wise in having an operation done?-if so, le was prepared! It would be well to educate the public, as such radiographs are being exploited to the disadvantage of our profession. It should be explained to them that no surgeon in his senses will guarantee an anatomical reposition by mechanical methods, Or a functional success by a well conducted operation. The moment the public is brought to believe that a fracture which is not operated upon is evidence of neglect, the peace of mind of the doctor is at an end.

I have ventured to suggest several reasons why we do not meet with infinitely better results than are recorded in the report, and some of these reasons I would briefly summarize.

We should be carefully taught the principles governing the reduction of fractures and their correct fixation.

We should not be ont-and-aut adherents of an operative, a fixation, or a mobilizing school. We should be shorrn the value of steady fixed extension, in contradistinction to forcible intcrmittent pulls succeeded by periods of relaxation.

The value of a correct alignment in conjunction with complete obliteration of shortening should be appreciated. A reduction quite incomplete during the primary anaesthesia may easily be made complete during the foilowing forty-cight hours. This correction is brought about by continued fixed extension, aided by appropriately placed pads; in other instances by approximating the lower to the upper fragment by posture of the limb.

We should study the causes of non-union from the clinical side, and in the application of splints avoid rigid circular compression. Splints should always be wider than the limb they protect. Delayed union in a certain proportion of cases is ineritable. Care must be taken not to carelessly relegate such cases to the more serious class of umunited fractures.

II c must realize that the academic period of consolidation authoritatively asserted is not accurate, and that bones which appear firm to the hand will yield after many weeks to the incidence of body weight.

Extensive callus exudation with pain on pressure most probably represents incomplete union.

After laving corrected by pulling and manipulation delayed and ununited fractures, the mere change in position and accurate retention will often rapidly bring abont firm union. To still further ensure success the bone may be percussed and elastic tubing applied above and below the fricture to produce congestion.

It should be tanght that a mal-united fracture interferes with the function of the limb by deflecting the borly weight from accurate incidence upon the joints above and below. Treatment should therefore be preventive.

Fractures above the elbow-joint should be fixed in supination and hyperflexion. Passive movements should not be commenced too early, and should be practised in the gentle manner I have indicated. The radial deformity of a Colles's fracture should be completely rectified; the ulnar prominence is of little consequence. For Pott's fracture the displacement of the ankle should be especially overcome and the inversion of the ankle secured. Steps should be taken when walking is begun to maintain the inversion.

In this way, by perfecting our mechanical methods, the necessity for operation will be materially lessenel, and we shall almost feel the sense of personai failure when the bone has to be exposed.

The indications for operation will clearly differ from the individual standpoint of the surgeon, and no rules can be laid down. The surgeon with least mechanical resource will operate most frequently.

Personally I operate upon the patella, certain fractures of the head of the radius, certain oblique or spiral $1 \ldots$ tures of the tibia, occasionally upon the olecranon. : $: u d$ upon any other case which may seem necessary. In malunited fractures I operate with considerable frequency. In my opinion it is best to operate while the pulley is at work.

The authors of the report call upon us to bear in mind " that the operative treatment of fractures is yet in it. infancy. . . Non-operative treatment, on the other hand, is thoroughly established." This statement should be modified, for in a progressive science nothing ever is tl:oronghly established. . Before we reach to new thing. we must ask ourselves if we have done the best by the old; and it is only by being critics of our own work that we can discover, each for himself, which procedure will in his own hands give the best result. We owe a debt of gratitude to Arbuthnot Lane. He has roused the surgical world from apathy on this question, and I feel assured that the reawakening will be to our eommon good, to the perfecting of our mechanical methods and the improvement of our operative technique.

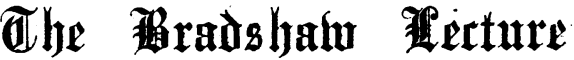

\author{
ov
}

\section{THE BIOLOGY OF TUMOURS.}

Delivered before the Royal College of Surgeosis of Exglaxd

By C. MANSELT MOLLLIN, M.A., M.D.Oxon., F.R.C.S., CONSELTING SERGEON TO THE I.ONDON HOSPITAL.

Mr. President aNd Gintlenes, - I am not going to attempt a definition of the word "tumour." I do not think that it is necessary; the time at my disposal is far too short, and I shall not employ the term in any but its most ordinary acceptation. The structures to which I refer are the growths, familiar to us all, that spring like buds from the normal tissues of the body, the texture of which they imitate more or less closely, draw all their nourishment from them, recognize no limits of size or shape, and never serve a useful purpose of any lind. They are so common that there is scarcely an adult without one, and they become so much more common as age advances, that in old people they can often be counted by the score.

\section{Absence of axy Niteral Lixe between Simple 1 ind} Malimint Growths.

Nor shall I attempt to kraw any hard and fast line between innocent and malignant tumours. There is no such line. Nature has never drawn one, and though, for our convenience, we separate tumours from each other, and group malignant growths together upon one side and innocent ones upon the other, between the two there is a borderland of which no man can say to which side the growths belong, nor even whether they do not belong at one time to one side and at another to the other. Every kind of so-called benign tumour, as Bland-Sutton has shown, contoins varieties that shade away indefinitely from the type species and at times become malignant. Malignancy is a purcly clinical term, and metastasis is mercly an accident of growth, absent from what are called benign tumours, not because the cells of which they ar'o composed would not grow if they were disseminated, but because, owing to their having reached a more advanced stage of organization, they can no longer exercise their primitive power of detachment and autotransplantation, and therefore never are disseminated unless it is done artiticially. The prescnce or absence of clinical characteristics such as these is not a satisfactory criterion for the classification of pathological growths. The system may lrave served in days gone by, when facts were few and little was known, but it should be abandoned now. 
Tumocrs Common to ald Axmals.

And I shall not confine myself in what I have to say to the tumours that occur in man. Every lind of tumour is met with in other animals, especially in those in which from domestication, or for other reasons. life is prolonged beyond the procreative age. So far as the biology of tumours is concerned, man is merely a highly specialized and much studied member of a class of mammalian vertebrata distinguished from all others by the ancient zoologists, not perhaps without a suspicion of humour, as Homo sapiens. As such I shall think and speak of him.

No Proof that Tluocrs are Cacseid br Parlsites.

No proof has ever been brought forward that the structures commonly spoken of as tumours, simple or malignant, are caused by parasites. All that can be said of them for certain is that they grow out from normal tissues like buds, which refuse to be bound by the laws that control the development of the rest of the body. Their behaviour is that of foreign growths, parasitic on the tissues, and their presence is resented and resisted by the tissues among which they lie exactly as if they were forcign growths.

\section{The Origin of Tumolrs in Growth Txcontrolled} BY Development.

A cell, or a group of cells in some particular part of the body, suddenly breaks off all relation with the rest. Development stops then and there. All idea of function disappears. Henceforth the cells in question never do any work or perform any duties. They have shaken them selves free from alt responsibilities. All that they do is to grow and multiply until they build up a formless, shapeless mass, composed of elements resembling in general appear ance the tissues from which they hare sprung. The only faculty they retain is tinat of growth-a faculty common to all living tissues, so long as they are living; and the measure of their growth is only limited by the supply of food. So long as this continues cood, no matter how the rest of the organism fares, they will continue to grow. But the growth of tumours differs from that of all other living structures in that it never serves any useful purpose. Tumours increase in size without aim or object. The cells of which they are composed arefunctionless. Like true parasites, tumours draw all they require for themselves from the rest of the body, give nothing in return, and thrive while it is being starved. They are the offspring of tissues that are no longer controlled by the laws that gorern the growth and development of the body. 'The first thing, therefore, in considering the ques. tion of their biology is to try and form a clear idea of the nature of these laws, their origin, and how it is they can be set aside in this way.

The Laws of Deteloparist.

Their orioin dates back almost to the beginning of all things, if not actually to that time when life made its first appearance upon earth, at least to a period so immeasurably remote that it is not in the power of our minds to form a conception of its distance. They came into being when the netazoa came into being, when for the first time the daughter cells of some primitive organism, failing to separate from each other after the parent har divided, as always had been done before, gained the adrantage of combination over their fellows and founded the new lingdom. Im measurably distant as that time is, for the oldest known of these living creatures, already very highly organized, are covered by $60,000 \mathrm{ft}$. of solid rock that has been deposited since they lived, there has been no change since. The laws that regulate the development of Homo sapiens norv are the same as those that regulated the derelopment of the hydra or its representative then. Each little mass of cells, consisting, it may be, of only a few units grouped together, whether it constituted the body of some primitive metazoon living in a remote geological epoch, or is formed by the clivision of a mammalian orum at the present day, obeys these laws.

The Division of the Primitive Organism into Germ and Somatic C'ells.

One of the chief factors that serves to distinguish living organisms from inert matter (though some doubt has been thrown upon this recently! is their power of absorbing and assimilating foreign material, in virtice of which they are able to replace the constant waste of living, increase in size, and, when the limits of size are reached, increase in number. Their one aim and object, if such language can be allowed, is to sustain the germ of life and hand it on unimpaired in strength and vigour from generation to generation. In the simplest forms, and in the earliest stages of those more complex, all -parts of the organism are endowed with equal powers. Every cell is capable of maintaining its own life, and every cell is capable, either by dividing or by throwing off buds, of maintaining the life of the race. What Weismann called the germ-plasma is shared by all alike. Very soon, however, both in the history of the race and in that of the individual, in accordance with the universal law of the division of labour, a distinction makes its appearance. The cells that compose the organism separate into two groups, distinguished from each other by the differentiation of their work. One of these becomes the germ organ consecrated to the formation of living germs and the perpetuation of the life of the race. The other, which comprises all the rest-the somatic cells, as they may be called-furnishes the ground work from which are built all the organs and tissues that are needed for the preservation of the life of the individual. In the smallest as in the largest, in the simplest as in the most complex, all the tissues of all the organs used in everyday life, whether the organism consists of an almost structureless body, such as that of the primitive hydra, or is elaborated to the degree of perfection that is reached in man, are formed and developed from these, the somatic cells.

At the first there is no difference that we can detect between the two kinds of cells. In the primitive metazoa, and in the earliest stages of the development of those ova in which such a question can be studied, one kind of cell can be made to replace the other, and undertake all its work. The two still possess equal powers. But as the differentiation of function advances the divergence soon becomes complete.

\section{The Germ Cells.}

From this time forth the whole energy of the $\mathrm{gcrm}$ organ is devoted to the production of ova, and the perpetuation of the race. It does nothing for itself. Sup ported and ststained by the structures formed out of the somatic cells to which it has given birth, it thrives and grows that it may transmit to the germs of the next generation all the powers it has inherited unimpaired. 'The race is continued without a break and generation succeeds generation; but except in the case of a few strange forms which seem to have persisted almost unchanged from time immemorial, the succeeding one is never quite the same as those that have gone before. There is always some modification introduced, however slight. No generation is exactly the same as that which preceded it. The daughter germs may appear to be exactly like the parent, but they nerer really are. Every germ cell before it divides or throws off a buid to form the daughter cell is modified in some way, be it ever so little. The somatic cells around it, upon which the maintenance of its life depends, themselves influenced by the ever-changing conditions around, cannot help influencing the germ cells in their turn. Always, therefore, before the germ cell is ready for division, it has become in some infinitesimal degree different from tho parent that gave it birth; and thus, though the continuity of the germ plasma remains unbroken from the earliest ages to the present time, the germ cells, and through them the structures built up around them out of the somatic cells to which they give birth, little by little become modified, and transmit their modifications from generation to generation, until at last the forms produced are far different from those that first came into existence, and far more complex. Countless offshoots from the parent stock have been thrown off in the course of ages in all directions. Some of these, eitlier because the supporting structures formed by the somatic cells around them became ill-suited to the requirements of the age, or because the vitality of the germ cells failed after a time, have died away and disappeared, leaving mercly fossil remains of the skeletal supporting structures to sliow what manner of beings they were. Many, with infinite variety of structure, ranging from the simplest blastulaform to that of man, persist still. New ones, evien more complex, may perhans be forming at the presen 
day. But whatever the framework formed by the somatic cells around them, the germ cells upon which the maintenance of the race depends are all direct descendants of the germs of the original primitive metazoa, and obey the same laws of growth and development.

The Somatic Cells.

On the other side of the picture, in contrast with these, are the somatic cells whose mission it is to form the framework for the support of the germ organ and the maintenance of the life of the individual. 'T'hese at the first were in all respects the equals of the germ cells. Like these they possessed the power of producing germs and of transmitting to their descendants all the properties they had inherited or acquired. But, as incritably happens when specialization begins, as the somatic cells became more and more perfect in their own particular line of work, their other powers began to wane. The first to disappear was the power of producing living germs that should serve for the perpetuation of the race. In the primitive metazoa all parts alike possessed this power, but at a very early period, even before the days of the fresh water liydra, it had already become restricted to onc small region of the body. This was marked off from the rest as the germ organ, and henceforth the power of forming ova was confined to this alone.

The next that was lost was the power of reproducing not the race, but the individual. In many of the lower forms of life, buds which are capable of developing into individuals as perfect as their parent can develop from parts of their body composed entirely of somatic cells. This, for instance, is common among Coelenterata, and even among animals so highly organized as nirine worms, many of which are capable of throwing off fully developed offspring from indifferent segments of their own body. Traces of this power may be found among animals far more highly organized than these, but only in the very carliest embryonic stages of life. In adult age, when differentiation has advanced further, reproduction of the iudividual from the somatic cells never takes place. With the loss of this disappears finally all power of liereditary transmission beyond the individual. The somatic cells may still reproduce their kind, and transmit their qualities to other cells within the limit of the individual, never to the race.

Long after the power of complete reproduction has been lost the somatic cells are still able to reproduce parts of individual organs or portions of the body that have been restroyed or injured. Whole limbs and other appendages, for example, can be regenerated among crustacea; and, though in a much lower degree, there is cvidence of the same power even in animals so highly organized as the Lacertilia. The curious little projections that occur sometimes in the human embryo, growing on the site of linbs that have been lost early in uterine life, may quite possibly admit of a similar explanation.

The next stage, that in which the somatic cells have lost the power of reproducing individuals and organs, but can still reproduce tissues similar to themselves, extends to a much later period both in the history of the race and of the individual. Comparatively extensive losses of simple tissues may be made good during cmbryonic life even among vertebrata; but as age advances this power, too, diminishes. In the adult it can be exercised only to a very limited extent, and in the case of the most highly specialized tissues, such as nerve ancl muscle, it is doubtful if it can be exercised at all.

Finally, all that is left to the somatic cells, all that remains of the powers they originally possessed equally with the germ cells, is that of simple growth, the ability to maintain size and structure unimpaired in the face of constant waste. Throughout, from the beginning of all things down to the present time, whether the development of the race is considered or its epitome, as shown in the devclopment of the individual, the process is the same. As specialization and differentiation advance, as the somatic cells adapt themselves to the work of forming the structures upon which the maintenance and protection of the germ depend, step by step they lose all the power of reproduction and transmission to the race they originally possessed, until they retain only that of simple growth. The support of the germ organ has become the sole object of their lives. Ererything else is given up, that this may grow and bring forth living orerms for the next generation each of which will in its turn build up a supporting frame work to serve the individual for the time being, and then be thrown away. The somatic cells themselves, and all the organs and tissues formed from them, no matter how complex or how highly specialized they are, are sacrificed each generation and destroyed. Their purpose is achieved when once the new germs are able to build up a protecting framework of their own. 'They may die at once, as in the case of many insects, where the procreative act is followed immediately by death; or if it is for the benefit of the race, if they possess qualities that will be of adrantage to the coming generation in the battle of life, as, for example, in the case of mammals, they may be continued a littlo longer, but the end is the same. The protective framework built up out of the somatic cells to serve the generation perishes with the generation; the continuity of the germ is preserved, to produce in each generation a framework for its own support. moulded, with more or less of moditication, on the plan of those that have gone before.

The destiny which thus awaits the somatic framerork is looked upon as quite natural where the simpler forms of life are concerned. When the next generation with its inheritance of living germ plasma is ready, the parent dics. Its mission is at an end. Its work is done and it disappears. But it is equally true of the move complex forms, no maiter how highly placed in the scale of organization they may be; and it is true not only of individuals, but of communities of individuals which have grown up and dereloped under the rigid and pitiless liws enforced by Nature, in which sentiment has no place. Nowhere, perhaps, is there a better illustration of this than in the case of the honey bee, in which, as Tickner Edwartcs has put it, the subordiuation not only of the individual but of the community to the conservation of the race seems to be pushed to its logical conclusion. Everything is subordinated to this one object. The lives of individuals are sacrificed wholesale under inexorable laws, if only it is for the good of the community. The aim and object of exist ence is the rearing of offspring, which in their turn shall devote themselves to rearing other offspring. There is a perpetual procession, in which each individual works and spends his life for some other individual, who will succeed him, and who in his turn will do the same. The individual is nothing, so long as the community prospers, just as in the living body the individual somatic cells and the struc. tures formed out of them are nothing so long as the germ can fulfil its mission.

The Origin of the Laurs of Development in the Wutual Relation of these cells.

Whether the organism is a primitive metazoon which will never attain a higher stage of organization, or an ovum that will develop into the most highly specialized of mammals, the force that regulates and controls its development, as distinct from the power of growth, which is an inherent pioperty of its cells so long as they are living, is the mutual influence that these germ cells and somatic cells exert npon each other and upon their fellows, com pelled thereto by the differentiation in their work. It is this influence, working with the driving force of inherit ance through countless ages, moditied in some infinitesimal degree by the surroundings in each individual case, that frames the laws that guide and control the development of the borly and the tissues that compose it.

The Oricis of Tumours.

Tumours do not obey these laws. They are tumours because they do not. Whaterer their structure, their growth and development are not conditioned in any way by the growth and development of the rest of the body. The degree of perfection to which they attain depends upon that of the tissue from which they spring, and the rate of their growth partly upon this, partly iipon the supply of food they can get. Whatever their origin no relation, such as that which holds good between the germ and somatic cells, ever exists between them and the parent body. They simply live upon it like parasitic growths upou a host.

Tumours from Germ Cells.

As there are two kinds of cells developed in the course of evolution with gradually diverging functions, so there are two kinds of tumours, one springing from the germ and 
the other from the somatic cells. With the former I shall not deal at any length. They may arise in various ways. Some are the product of fission of the primitive germ. In such a case, if the two halves contain an equal proportion of germ cells, and if they become separate from each other in the course of growth, two equal and perfect individuals result. Others originate by a process of unequal fission or gemmation, the formation of a more or less perfectly developed bud which grows out into a structure sometimes almost as complex as the parent. Others may be caused by the detachment and displacement, perhaps by accidental violence, of a few of the germ cells, which either remain in situ or are buried deep among the somatic cells and then begin to develop; and others, again, especially those which originate late in life, may be the result of some as yet unknown stimulation of germ cells that are lying latent in the germ organ. But whatever the mode of their origin, the essential feature of these tumours is that they are outgrowths from germ cells, and therefore possess, in greater or less degree, the same powers as all such outgrowths. The germ cells have been over-stimulated in some way, or over-fed, or injured, and as a consequence give birth to these irregular structures instead of, or in addition to, the natural ones. The difference between them is one of degree, not of kind.

Like the normal structures that are produced from germ cells, these abnormal ones form their own somatic framework, though, as might be expected, this differs widely in the degree of its perfection. At one end of the scale there may be a complete and separate individual, in all respects as perfect as the parent one, capable of maintaining itself and of perpefuating the race. At the other end, because the germ cells are either few in number or have lost much of their germinal power, there may be merely an irregular mass, a dermoid, built up out of the wanton over-production of epiblastic cells. In either case the different cells that compose these structures bear to each other within the limits of that structure the same relation (so far as their development will allow them) as that which exists between the different celis of the parent body. But no such relation ever exists between them and those of the parent. Except that they draw their food supply from it and give up their waste products to it, the cells of the tumour own no connexion of any kind with those of the stock from which it grew. They neither influence it nor is it influenced by them. Their relation to it is that of an independent organism, developed independently from the germ cells, deriving its nourishment from the parent in the same way that a parasite or a foreign growth might, or in a few exceptional cases absolutely and entirely separate.

Tumours from Somatic Cells.

Putting upon one side these, which are comparatively rare, all the rest, forming the vast majority of what are commonly called tumours, originate by a process of budding from the somatic colls after their differentiation from the germ cells has taken place, or from structures developed from them. These tumours owe their origin not to the action of germ cells, but to the release from control of what is left of the power of reproduction which the somatic cells originally possessed in equal degree with the germ cells, but which was suppressed as these cells became specialized for the support and maintenance of the germ organ.

A few of these tumours make their appearance very early in life, at a time when specialization is not yet far advanced and the powers the somatic cells originally possessed are but slightly impaired. They grow out as buds, which in some instances attain such a high degree of complexity that they will stand comparison with those I have already mentioned as originating from detached portions of the germ organ. Indeed, it is not always possible to say that this is not their real origin, and that their apparent descent from somatic elements is not actually due to their having originated from detached portions of the germ organ that have been accidentally displaced and buried among somatic structures. A few others take the shape of organs or parts of organs growing out as buds from the extremities or other portions of th body that develop comparatively late. Theoretically, these should be capable of being distinguished by the date of their appearance, but the early stages of the develop. ment of the mammalian ovum are so much compressed, and represent in the course of a few hours such an infinity of ages spent in the evolution of the race, that it is not possible to draw distinctions of this kind.

All these tumours, however, are comparatively rare. The total number is very small in comparison with that of what may be called ordinary growths. They nearly all originate early in life, though they may not always make their first appearance then, and they stand apart in a class by themselves. By far the greater number of the tumours that are developed from the somatic structures grow out as buds much later than this, long after the early stages of life have been passed and the differentiation of the tissues completed, and become more and more common as age advances. These rarely consist of anything more complex than simple tissues. The cells from which the buds originate have already reached such a high degree of specialization that they have lost the power of forming everything except tissues somewhat like themselves; more elaborate reproduction is no longer possible. If the parent cells have already reached their final adult stage the increase in size of the budding tumour is very slow. If, on the other hand, they are still immature and capable of rapid multiplication like those, for instance, that aro present, often in considerable numbers, both in epithelial and mesoblastic structures, for the purpose of replacing the losses caused by the wear and tear of everyday life, or the destructive action of persistent irritation, growth may be very rapid. In the one case the resulting tumour is built up of tissues that have practically attained their full development; its increase in size is slow, and it never invades the rest of the body. In the other it consists of cells which retain so much of their primitive energy of growth that; if once released from the restraint of the laws that would compel their further development, they grow and multiply in a manner only surpassed by the cells that compose the germ layers of the embroyo. They increase without limit, and without an attempt at higher differen. tiation, and they spread everywhere in the directions of least resistance, partly of their own efforts, by a process of autotransplantation, partly carried along in the blood stream, or in the lymphatic channels, and unless destroyed as foreign bodies by the tissues among which they lie, they reproduce their kind wherever they come to rest.

The Principle underlying the Growth of Sonatic Tumours.

Whatever form is assumed by the tumours that originate from the somatic elements or the structures derived from them, the underlying principle of their growth is the same. The power that would compel the higher differentiation of the cells that compose them ceases to act. The cells that form the tumour bud cease to develop further and never do any work. They cease to bear any relation to the rest of the body, except that they draw their food supply from it and give up their waste products to it. They do not influence other tissues in any way nor are they influenced by them. They con. tinue to grow and multiply, perhaps with all the greater energy because the force that would have been consumed in raising the cells to a higher plane of differentiation is available now for growth. The tumour cells go their own way, never rise to a higher plane, never do anything for the rest of the body, but, like parasites, devote the whole of their energy, which should work for the common good, to their own increase in size and number. What remains to them of their primitive reproductive power is released from all control and guidance.

How is it that the tissues at one small spot in the body are suddenly able to assert themselves in this way? How is it that almost from one minute to another they can shake off all allegiance to the other tissues, and, except that they are dependent upon the rest of the body for their food, grow upon it, entirely independently of its growth, and thrive while it may starve? How is it that from normal tissues, doing their normal work, they can suddenly develop into structures like parasites that drain the body of its sustenance and do nothing for it in return?

The Controlling Power of Hereditary Transmission.

There is only one answer to questions such as these. The progressive development of the organs and tissues of the individual, as of the race, is the outcome of the mutual relations that have been built up in the course of ages 
between the infinite variety of cells of which the body is composed, transmitted from generation to generation. Environment and the actual working of the organs and tissues in the individual are but forces of the moment. The real controlling power is the hereditary transmission of the relations which the different parts of the body have exerted upon each other through immeasurable time, and which have been handed down in ever-increasing number from countless ages. It is this that directs development and differentiation, and keeps growth in check. If it fails from any cause, or if it is overpowered by the forces of the moment, whether they form part of the environment or originate in the body itself, development and differentiation come to an end, organs fail to attain their normal perfection, and tissues remain at that level of specialization at which they happen to be at the moment, incapable of work because of their imperfect development, but with their power of growth not only intact, but released from all restraining influence, and, it may be, even increased in vigour.

To put it very crudely, the tissues have become what they are in virtue of the accumulated effect of all that they have done for the rest of the body, and that the rest of the body has done for them through countless ages. Their differentiation is the outcome of the work of their predecessors. Each cell, as it comes into being, has its destiny' marked out for it by virtue of the relations it bears to the rest. It is bound by the force of heredity to develop in one direction, and to reach a certain stage of perfection, that it may be able to carry on its work. But sometimes, just as the development of an organ is arrested without its power of growth being impaired, so the differentiation of a budding tissue may be arrested, and its power of growth be left unimpaired. Somewhere, in some part of the body, the force that should compel the evolution of the reserve cells, or of those young cells that are constantly being formed to take the place of those worn ont, suddenly ceases to act. All progress comes to an end. It may be at an early stage, while the young cells still retain all their embryonic vigour; or it may be late, when they have all but reached their final form. In either case growth continues unimpaired, because growth and its congequence, increase in number which is the outcome of continued growth, are in no way dependent upon these relations. The work the tissues have done in the past has no influence over their power of growth except through the differentiation it induces. Growth-ceaseless, continuous growth-is a property inherent in living structures, so long as they are living-a property which is controlled and moulded by advancing differentiation, but which, if differentiation is checked, especially in its earlier stages, is capable of reasserting itself with all its old energy, or even with increased energy, as the force which would have been consumed in carrying specialization to a higher plane is now available for growth alone. The result is a tumour-an irregular formless mass of badly differentiated tissue which grows independently and continuously, which does not acknowledge any obligation, or do any work, and is so much a foreign element among the tissues in which it lies that its presence is resented and resisted by them in proportion to the activity with which its size increases.

If the power of hereditary transmission continues unimpaired throughout life, the development of the tissues is perfect and remains perfect; their work is properly carried out, and all the complex relations existing between them are maintained intact. If, on the other hand, it fails, as it may fail in advancing age from mere lapse of time, or when, owing to the long persistence of some local irritation, there is a very rapid production of myriads of young cells, the evolution of the tissues stops, it may be early in their life-history, or it may be late; growth continues, and the product becomes a tumour which continues to increase in size with a rapidity that depends upon the degree of differentiation already attained by the cells from which the bud first grew, and the supply of food that they can get.

It may be the fault of the tissues at that particular spot, and the origin of the tumour be purely local, as in the case of growths caused by $x$ rays or by soot, agents which seem to be capable of making such tumours as papillomata and epitheliomata grow from the epidermis in any part of the body, in any person. Or it may be in some measure the fault of some other structure, perhaps far distant, with which the tissue from which the tumour springs stands in some working relation, and only the locality be determined by the local agent. In either case the essential feature is the cessation of the progress of differentiation and the removal of all restraint upon growth. Something-some one of the forces of the momenthas disturbed the relations that have been evolved in the course of ages between these particular cells and the rest of the boaly. The differentiation of the tissues which these relations have built up step by step through countless generations comes to an end; growth continues, and a tumour is formed.

\section{Tumours due to Involution Changes.}

Nor does this explanation hold good for those tumours only that spring from the somatic cells and are formed of more or less highly differentiated simple tissues. It is no less true of those strange growths that sometimes develop from fetal or embryonic relics, such as the post-anal gut, the thyroglossal canal, and many others. The hereditary transmission of the relations that have grown up between the various tissues of the body and of the structural features that have been produced by them, implies not only the progressive advance of those tissues that are of use, but no less, also, the recession and disappearance of those that have ceased to be of use. Evolution stops when the power of hereditary transmission fails; but so also does involution. Fragments of organs that should dis. appear and be absorbed persist, and, continuing to grow and to work after a fashion, become the nucleus of what are sometimes colossal tumours.

\section{The Inheritance of Tumours.}

In this way, moreover, and in this way only, is it possible to account for the apparent inheritance of tumours. Tumours, like other acquired features, are not inherited, yet there can be no question that certain families are much more prone to the formation of tumours, and of particular kinds of tumours, than others. It is well known how the power of hereditary transmission varies in strength in different families. Some special features are handed down unchanged from one generation to another, while others can scarcely be traced. The same thing is true of the tissues that build up those features. In some the hereditary power is so strong that they maintain throughout life the full perfection of their development, and growth is never allowed undue licence. In others the power is weaker and fails to a greater or less degree. Then if by any chance that part is exposed for a sufficient time to the action of one of the forces of the moment, so that, for example, it is necessary that the tissues should be replaced with great rapidity, the evolution of the young growing tissue stops because the driving power has failed, and growth, freed from its control, asserts itself with all its energy. It is not the tumours that are inherited, but the strength of the driving force that directs development and controls growth. This, in the case of some particular tissue, may fail in several members of the same family for generation after generation, just as may the transmission of some special feature.

The Simultaneods Growth of Tumours.

This, too, explains the well-known liability of homologous tissues to become almost at the same time the seat of similar tumour growths. Such an occurrence is most common in connexion with non-malignant tumours such as fibromata and lipomata, but it is not confined to these. I have known, for instance, duct carcinoma develop at the base of the nipple in both mammary glands within three months. The strength of the power which has guided tile differentiation of the tissues through immeasurable time, and which controls their inborn capacity for limitless growth, is naturally the same in tissues of similar descent. It maintains its control, or it fails before the action of the forces of the moment in the same way in them all

As it is the work of the tissues, their own and that of past ages, that step by step has made them what they are, it has been suggested that it is something connected with their work that cuts their evolution short and allows their power of growth to assert itself unchecked, and that the origin of tumour buds is to be found in a functional disorder of some kind. But while it is quite true the tissues that compose tumours never do any work, the failure to work 
is the consequence, and not the cause, of the arrest of evolution. Tumour tissues are imperfect; and remain imperfect, and work cannot be expected of such. Their differentiation has been arrested before they were capabls of work. Tumour tissues never work because, with the rarest possible exceptions, they never reach the perfection of maturity. The exception proves the rule; a few mammary adenomata attain such a high degree of parfection that secretion has been known to take place in certain portions of them. The vast majority falls far short of this.

The Arrest of Development of Organs.

If it is asked what could interfere with the power of hereditary transmission to such an extent as to cause the arrest of the differentiation of the tissues in one part of the body and the formation of one kind of tumour, or the arrest of their involution in another and the formation of another kind, I can only point to the analogy of the arrest of development of organs, and say that I can see no reason why such a power may not fail from mere exhaustion, as for instance in old age, either of organs or of individuals, when it is notorious that the liability to tumour growth becomes greater and greater, or from excessive action, as when an enormous number of young cells is produced with great rapidity in response to some persistent chronic irritation. Whether the action, or want of action, of any organ in the body could have a similar influence over the power of hereditary transmission and bring its work to a sudden stop it is impossible to say. There is one structure in the body at least that appears to be capable of abrogating the laws that control the growth of tissues and of enabling them to increase ii size without limit; but we know too little of these things as yet. The study of physiology is of yesterday. At our best we have only a very general acquaintance with some of the most conspicuous individual actions of what may be called the gross mechanical apparatus of the body. We know next to nothing of the essential organs of life, those that really matter where growth and development are concerned. We are only just beginning to grasp the fact that many absolutely insignificant-looking structures, some of them almost microscopic in size, possess the most extraordinary power over growth, and even over life itself; and we are only just beginning to realize that no organ or tissue in the body exists for itself alone, but only in relation with every other organ and tissue. It may be that when we know more about these things some structure will be found which has some control over hereditary trans. mission and the development of tissues as distinguished from their growth. Until then-and it must be admitted the prospect is not a good one-all our hopes of finding such a thing as a cure for the growth of tumours (for amputation, though it may free the patient from the consequences, can in no sense be regarded as a cure) must rest either upon finding some remedy which, like Coley's fluid, can directly kill the tumour cells without endangering too greatly the vitality of the normal tissues, or upon stimulating to increased energy the normal tissues that surround the tumour until they are able to treat those degenerate cells that have failed to attain their full development and have continued to grow at the expense of the organism without being of any service to it, in the same way that the workers treat the drones.

DR. EDGAR BATES has examined all the children in the Dee and Washington schools of Ogden, Utah; 890 pupils were tested with the illiterate card, and 184 were found to be suffering from eyestrain. Of these 134, or 73 per cent., had headaches; 114 complained of symptoms originating in close work, and 57 of them stated that words became blurred; 34 had blepharitis. A gradual increase of cases was noted from the kindergarten up to the highest forms. Many of the pupils stated that their symptoms were first noted after an attack of measles or scarlet fever. Some of the children who complained of eyestrain were wearing glasses, but they had been fitted by an optician without the use of a mydriatic, which Dr. Bates considers futile; most ophthalmologists will subscribe to this opinion. In reading this paper, which appears in Ophthalmology for January, 1912, it is necessary to remember that eyestrain is far more frequent in America than it is here, and also that leading questions as regards headache were put to the children.

\section{THE FUNCTIONAL NATURE OF THE CAECUM AND APPENDIX.*}

By ARTHUR KEITH, M.D.,

CONSERTATOR OF MUSEUM, ROYAL COLLEGE OF SURGEONS OF ENGLAND.

Every year the opinion gains ground that the great bowel, from appendix to rectum, has become, so far as man is concerned, a useless and dangerous structure. Exactly ten years ago (October, 1902) Dr. Barclay Smith ${ }^{1}$ of Cambridge gave a clear expression of this new conception.

"If there is any truth," he wrote, "in the suggestions offered in this paper, they have an important practical application as regards the large intestine of man. From the nature of his diet a reliance on extrinsic digestive aid as is furnished by bacteria is no longer a physiological necessity. The statement is perhaps a bold one, but I am convinced that the large intestine is practically a useless encumbrance to him."

In the following year (1903) appeared Metchnikoff's famous book on The Nature of Man. ${ }^{2}$ In that work (p. 69) the new conception receives a more decisive statement:

It is no longer rash to say that not only the rudimentary appendix and the caecum, but the whole of the large intestine are superfluous, and that their removal would be attended with happy results.

Before either of these statements had been made Mr. Arbuthnot Lane ${ }^{3}$ had reached the conclusion that the human caecum and ascending colon served, in a certain class of cases described by him, as a "cesspool," and put his new conception into practice either by excluding the great intestine from the digestive tract by "short-circuiting," or, at a later date, by its complete excision. The result of his operations shows (1) that life is possible without a great intestine; (2) that in certain cases the conditions of life are improved. It is very apparent that Mr. Lane's pioneer operative measures are finding every year an increasingly wide application, and that the views of Metchnikoff and of Barclay Smith are gaining in acceptation amongst medical men.

\section{Theories regarding the Uses of the Caecum and CoLon.}

If these statements are well founded-if the great bowel is as useless and injurious as is said-then medical men are face to face with a condition which threatens the health and survival of modern civilized races. Before assigning so large a part of man's digestive tract to the list of his useless structures, it will be well to inquire what we know regarding the function of the great bowel as a whole, and the uses of its parts in the various members of the animal kingdom. Such an inquiry brings home to us that our knowledge of the function and sig. nificance of the great bowel is vague and unsatisfactory. We do not know; in any animal whatsoever, the exact function or functions of the great bowel; so far we have only guessed at them.

The subject is one which engaged the attention of John Hunter; in his collection there are many specimens which illustrate the structure of the various parts of the great bowel in all classes of vertebrates, but unfortunately he left only the briefest record of the conclusions he had formed regarding their uses. "If we could understand," he wrote, "the use of the ileo-caecal valve, then we should understand the uses of the caecum." 4 He observed that there was a material difference between the contents of the ileum and of the caecum ; the contents of the caecum and colon underwent putrefactive changes, and in his opinion the ileo-caecal value was to prevent the putrid contents of the caecum from regurgitating within the ileum. In a case of gun-shot wound of the abdomen he observed that the colic contents had passed upwards in the ileum, a result which he supposed might be due either to a lesion of the nerve supply of the bowcl or to a reversed action of the intestine. In the light of our modern knowledge it is interesting to note he had observed that the colio contents were not putrid at birth nor did the caecum of the newly-born contain gas. He was also familiar with the fact that the caecum was small, the colon short, and 